\title{
THE LANDSCAPE OF OURO PRETO (MG, BRAZIL) THROUGH ANALYSIS OF ANTHROPIC ACTIVITIES IN RELATION TO THE ENVIRONMENTAL CONSERVATION
}

\author{
Rossi Allan Silva ${ }^{1 *}$, José Aldo Alves Pereira ${ }^{1}$, Inácio Thomaz Bueno ${ }^{1}$, Luís Antônio Coimbra Borges ${ }^{1}$, Fausto \\ Weimar Acerbi Júnior ${ }^{1}$ \\ ${ }^{1}$ Federal University of Lavras, Department of Forest Science, Lavras, Minas Gerais, Brazil - rossiallan@gmail.com*; j.aldo@dcf.ufla.br; \\ inaciotbueno@gmail.com; luis.borges@dcf.ufla.br; fausto@dcf.ufla.br
}

Received for publication: 27/07/2017 - Accepted for publication: 16/03/2018

\begin{abstract}
Understanding the complex interaction among landscape elements can improve the management of environmental conservation and anthropic activities. The aim of the present study was to develop a methodology that assists in the planning and management, harmonizing the conservation of natural areas with anthropic activities in the city of Ouro Preto (state of Minas Gerais, Brazil). The methodology used the weighted overlay algorithm of the ArcMap ${ }^{\mathrm{TM}}$ software, which weights among land use characteristics. In the present study, the following classes were used: slope; relief; soil; landscape ownership by individuals; presence of protected areas; economy; and type of management applied to the preservation or conservation of forests and fields. The most relevant anthropic activities (contained in the classes) were simulated, to the detriment of the forest reduction, according to their spatial locations. Consequently, a map with five weights was obtained, which were verified in the field with their respective descriptions. The physical changes occurred as a reflection of the economy, promoting environmental effects, especially related to the mining, tourism, agricultural and livestock activities, besides conservation of natural areas. All of them require ideally a shared management. The interactions among simulated classes aid to increase information in future planning. Understanding the anthropic and natural processes, which have taken place by either consolidation or isolation along the territory, can assist decision-making on the current directions and in the definition of future proposals. It was noticed that the landscape needs a management which creates sustainable alternatives for anthropic activities.

Keywords: Ecological modeling, economic activities, mining, tourism, agriculture.
\end{abstract}

\section{Resumo}

A paisagem do município de Ouro Preto $(M G)$ por meio da análise das atividades antrópicas frente à conservação do meio ambiente. O entendimento da complexa interação dos elementos da paisagem pode melhorar a gestão da conservação do meio ambiente e atividades antrópicas. O objetivo da pesquisa foi desenvolver uma metodologia que auxilie no planejamento e gestão, compatibilizando conservação de áreas naturais com atividades antrópicas, no município de Ouro Preto (MG). A metodologia utilizou o algoritmo weighted overlay do programa ArcMap ${ }^{\mathrm{TM}}$, que faz uma ponderação entre os planos de informação. Neste trabalho, utilizou-se, como planos de informação: declividade; relevo; solo; apropriação da paisagem pelos indivíduos; presença de unidades de conservação; economia; e tipo de gestão aplicada à preservação ou conservação das florestas e dos campos. Foram feitas simulações de expansão das atividades antrópicas (contidas nos planos de informação) mais relevantes, em detrimento da redução das florestas, de acordo com suas localizações espaciais. Como resultado, obteve-se um mapa com cinco pesos, os quais foram verificados em campo, com suas respectivas descrições. As mudanças físicas se produziram como reflexo da economia, promovendo impactos ambientais, principalmente relacionados às atividades de mineração, turismo, agropecuária e conservação de áreas naturais. Todos necessitam, idealmente, de uma gestão compartilhada. As interações dos planos de informação simulados ajudam a incrementar informações nos planejamentos futuros. A compreensão dos processos antrópicos e naturais, que ocorreram seja por adensamento ou isolamento ao longo do território, pode auxiliar nas tomadas de decisões sobre os rumos conduzidos atualmente e na definição de propostas futuras. Notou-se que a paisagem necessita de uma gestão que crie alternativas sustentáveis para as atividades antrópicas.

Palavras-chave: Modelagem ecológica, atividades econômicas, mineração, turismo, agropecuária.

\section{INTRODUCTION}

In order to broaden the view of managers on the environment in which they live and aid in understanding the landscape completely, it becomes necessary to understand the interactive effects related to the amount and configuration of habitats. This activity is complex and goes beyond just assessing the decrease of the forest area,

FLORESTA, Curitiba, PR, v. 48, n. 3, p. 343-354, jul/set. 2018.

Silva. R. A. et.al.

ISSN eletrônico 1982-4688 
since there are several non-linear interactions and which show synergistic and antagonistic effects (VILLARD; METZGER, 2014). In addition, what people mean by territory must be understood because changes in habitat configuration are related directly to individuals' actions on natural resources and their interrelationships (RAYMOND et al., 2015).

In this sense, there is a need to implement environmental assessments in a strategic way, which will support managerial decisions, foreseeing the effects of environmental policies, plans and programs (PELLIN et al., 2011). Thus, it is necessary to consider the main anthropic activities performed on each territory in order to understand the relationship among these activities, the environmental conservation and the growth prospects in short and long term.

The landscape must be worked on its various scales, however, it still lacks much research. An example is the case of understanding the influence of spatial heterogeneity of biological diversity (RAPPAPORT et al., 2015). With the insertion of man in space, unavoidable interference, this understanding requires greater care during the assessment of its integration with ecosystems. Current technologies can aid in predicting the direction of evolution. However, Larrue et al. (2013) point out that the determinations to regulate the landscape uses can cause distortions among the different uses and other resources present in the territory.

This research has developed a simple and low cost methodology, focusing on the conservation planning and management of natural areas present in the municipality of Ouro Preto, state of Minas Gerais, Brazil. To reach such objective, a map showing the intensity of anthropic activities using geoprocessing tools was proposed, in a municipal scale. To validate the methodology, the activities and the main environmental effects in the landscape were described so that the indications of the municipal spatial direction of the management were defined, with a view either to adequate conservation measures or boost economic activities.

\section{MATERIAL AND METHODS}

The watersheds include strategic tributaries that supply the Rio Doce and the São Francisco River, especially the Rio das Velhas, which supplies water to the state capital (Belo Horizonte). The present plant physiognomies are: Semi-deciduous forest montane, rock and field. The main soils are: Cambisols, latosols and entisols. The relief is very variable and with predominantly mountainous topography, followed by undulated and, in smaller area, flat. It shows Cwa climate in the lower regions and Cwb in the highest ones.

The thematic map was developed in order to define the trends of use and growth of the set of economic activities in face of the environmental conservation of the municipality of Ouro Preto, based on the premises of sustainable development. Information regarding the soil, relief, slope, the landscape ownership by individuals, the presence of conservation units, economy and type of management applied to the preservation or conservation of forests and fields were analyzed. These data were used in the shape and raster formats within the limits of the municipality and were processed by the softwares eCognition $®$ and ArcGIS $®$, with the support of the Laboratory for studies and projects in forest management (LEMAF) of the Federal University of Lavras (UFLA).

The RapidEye images (high spatial resolution of $5 \mathrm{~m}$ ) of the year 2011 were adopted for the study. For the mapping of land use and land cover, the object-oriented classification technique was adopted using the multisolution segmentation algorithm of the eCognition software, which controls the parameters of scale, shape, color, compactness and smoothness, being a procedure widely used in studies related to earth science. In order to define the size of segments representing objects which compose the landscape in terms of land use and land cover in the city of Ouro Preto, tests were performed with the input values of the parameters. After evaluating the results, values were defined for the parameters scale, shape and compactness.

The classes of land use and land cover to be mapped were based on the most expressive land uses (SILVA et al., 2015): semi-deciduous seasonal forest montane; natural fields; field with rocky outcrop; water; urban area; eucalyptus; pasture; exposed soil; mining; and others. In order to aid the separability among the classes, the following distinguishing parameters were inserted: the average values of the reflectance of objects in different bands; the normalized difference vegetation index (NDVI); the brightness (average spectral value of an object considering all bands of the image); the ratio among bands; the brightness among bands; and the maximum difference (calculated by the difference of the minimum value of an object by its maximum value). The last step was the process for validating the classification from the field trips and the visual interpretation of the images. The resulting thematic map was validated with a confusion matrix and a Kappa coefficient, which provide confidence percentage values of the classification.

The methodology for evaluation of priority sites for the preservation of natural resources or the exercise of economic activities is based on the overlapping of classes. In order to define the regions and types of investments to be prioritized, the hierarchical decision process was used (CROSSMAN et al., 2009). Therefore, priority was given to certain regions according to their current spatial and social organization in the landscape. Growth limits 
of the most significant activities in the municipality were simulated, such as the classes of forests, mines, pastures, urban areas, eucalyptus plantations, legal restrictions with emphasis on protection (integral protection area, sustainable or other), soil types, and slope classes. An influence value was given for each class, totaling $100 \%$, which gave greater precision in the results (Table 1).

Table 1. Influence of classes used to determine the intensity of anthropic activities in the municipality of Ouro Preto (state of Minas Gerais, Brazil).

Tabela 1. Influência dos planos de informação utilizados para a determinação da intensidade das atividades antrópicas no município de Ouro Preto (MG).

\begin{tabular}{lc}
\hline Classes & Influence (\%) \\
\hline Forest edge & 15 \\
Slope & 10 \\
Vicinity of urbanized areas & 10 \\
Vicinity of Eucalyptus areas & 15 \\
Vicinity of mining areas & 15 \\
Vicinity of pastures & 15 \\
Legal restrictions for protection & 10 \\
Soil type & 10 \\
\hline
\end{tabular}

After choosing the layers to be used, weights were defined for the most significant classes according to the growth trends. Predefined spacing limits were adopted based on the limits of urbanization, pastures, mining, eucalyptus and forest plantations (Table 2). Five intervention levels (weights) were used for the simulation. The first level is related to the greater perturbation spacing used in the simulation and, therefore, to the sites with lower probability of deforestation or degradation. The fifth level refers to the greater proximity to the class analyzed, i.e., to the greater probability of deforestation or degradation. For the forest class, five classes were also defined in reverse way (from the edge to the inside) because the greater deforestation or degradation possibilities occurring in these classes go inwards the forest.

Table 2. Weights for vicinity of the most significant land use classes used to process the thematic map for intensity of anthropic activities in the municipality of Ouro Preto (state of Minas Gerais, Brazil).

Tabela 2. Pesos para a proximidade dos limites das classes de uso do solo com maior significância, utilizados para o processamento do mapa temático de intensidade de atividades antrópicas no município de Ouro Preto (MG).

\begin{tabular}{lccc}
\hline Classes & Spacing & Weights & Direction \\
\hline \multirow{3}{*}{ Urbanization } & 0 to $100 \mathrm{~m}$ & 5 & \\
& 100 to $200 \mathrm{~m}$ & 4 & edge to outside \\
& 200 to $300 \mathrm{~m}$ & 3 & \\
300 to $400 \mathrm{~m}$ & 2 & \\
& 400 to $500 \mathrm{~m}$ & 5 & edge to outside \\
Pastures & 0 to $100 \mathrm{~m}$ & 4 & \\
& 100 to $200 \mathrm{~m}$ & 3 & \\
& 200 to $300 \mathrm{~m}$ & 2 & edge to outside \\
& 300 to $400 \mathrm{~m}$ & 1 & \\
Mining areas & 400 to $500 \mathrm{~m}$ & 5 & \\
& 0 to $100 \mathrm{~m}$ & 4 & edge to outside \\
& 100 to $200 \mathrm{~m}$ & 3 & \\
\hline \multirow{3}{*}{ Eucalyptus areas } & 200 to $300 \mathrm{~m}$ & 2 & edge to inside \\
& 300 to $400 \mathrm{~m}$ & 1 & 5 \\
\hline \multirow{2}{*}{ Forests } & 400 to $500 \mathrm{~m}$ & 4 & 3 \\
\hline
\end{tabular}

FLORESTA, Curitiba, PR, v. 48, n. 3, p. 343-354, jul/set. 2018.

Silva. R. A. et.al.

ISSN eletrônico 1982-4688 


\begin{tabular}{ll}
\hline 200 to $300 \mathrm{~m}$ & 3 \\
300 to $400 \mathrm{~m}$ & 2 \\
400 to $500 \mathrm{~m}$ & 1 \\
\hline
\end{tabular}

The considered legal restrictions related to the conservation units (more restrictive), sustainable use (less restrictive) and the outside of these areas (used as basis for weights of the National System of Nature Conservation Units - SNUC) used different weights (Table 3). The soil types (Table 4) show more restrictive weights for those with greater erosion vulnerability, according to the relief in the municipality of Ouro Preto (soil map of the Brazilian Agricultural Research Agency - EMBRAPA). A higher weight was given to the slope of flatter classes, decreasing to the fifth level in the steepest class (Table 5), being related to the greater ease of deforestation or degradation from the flatter areas.

Table 3. Weights of legal restrictions for conservation units used to process the thematic map for intensity of anthropic activities in the municipality of Ouro Preto (state of Minas Gerais, Brazil).

Tabela 3. Pesos das restrições legais para as unidades de conservação, utilizados para o processamento do mapa temático de intensidade de atividades antrópicas no município de Ouro Preto (MG).

\begin{tabular}{lc}
\hline Legal restrictions & Weights \\
\hline Integral protection & 1 \\
\hline Sustainable use & 3 \\
\hline Remaining area & 5 \\
\hline
\end{tabular}

Table 4. Weights for soil types used to process the thematic map for intensity of anthropic activities in the municipality of Ouro Preto (state of Minas Gerais, Brazil).

Tabela 4. Pesos para os tipos de solos utilizados para o processamento do mapa temático de intensidade de atividades antrópicas no município de Ouro Preto (MG).

\begin{tabular}{lc}
\hline Soil type & Weights \\
\hline Latosol & 5 \\
\hline Cambisol & 3 \\
\hline Entisol & 1 \\
\hline
\end{tabular}

Table 5. Weights for slope classes used to process the thematic map for intensity of anthropic activities in the municipality of Ouro Preto (state of Minas Gerais, Brazil).

Tabela 5. Pesos para as classes de declividade utilizados para o processamento do mapa temático de intensidade de atividades antrópicas no município de Ouro Preto (MG).

\begin{tabular}{cc}
\hline Slope classes $(\%)$ & Weights \\
\hline 0 to 3 & 5 \\
\hline 3 to 8 & 4 \\
\hline 8 to 20 & 3 \\
\hline 20 to 45 & 2 \\
\hline$>45$ & 1 \\
\hline
\end{tabular}

The weights are based also in State Law No. 18,030, from January 12, 2009, of Minas Gerais, Brazil. This law establishes the distribution of the revenue share of the State Tax on Circulation of Goods and Services (ICMS) belonging to the municipalities, according to the factors under study in the simulation: geographical area, population, cultural heritage, environment, mining municipalities, water resources, tourism, among others.

To generate the thematic map with the five classes, the weighted overlay algorithm of the ArcMap ${ }^{\mathrm{TM}}$ software (ENVIRONMENTAL SYSTEMS RESEARCH INSTITUTE, 2008) was used. In addition to the spatial location, this algorithm uses the weights previously defined for each level and the influence values for each class specified in the thematic maps.

For a better understanding of the weights used and for validation of the map generated, a discussion was made based on the landscape dynamics. According to the classes and relevant anthropic activities, data obtained were used partially through technical field visits and interviews for the discussions. During field visits, data related to the management structure, visible environmental effects and others were observed. To include information on the population, semi-structured interviews were conducted with public and private managers residing in 13 districts of the city of Ouro Preto (randomly chosen), tourists, public and private workers, retirees living in the region for 80 years, among others. 


\section{RESULTS AND DISCUSSION}

\section{Analysis of classes and technical results}

The image resulting from the classification used the scale parameter defined in reference to the average size of urban infrastructures. Such parameter determined the average size of the image or object used. The segmentation parameters obtained the following values: scale parameter $=250$, shape $=0.3$, and compactness $=0.3$. The overall accuracy was $90.60 \%$ and the Kappa coefficient was 0.9056 . The classification results were tested based on field observations, in which the entire thematic map was revised. When necessary, it was edited manually in order to correct algorithm errors (Figure 1).

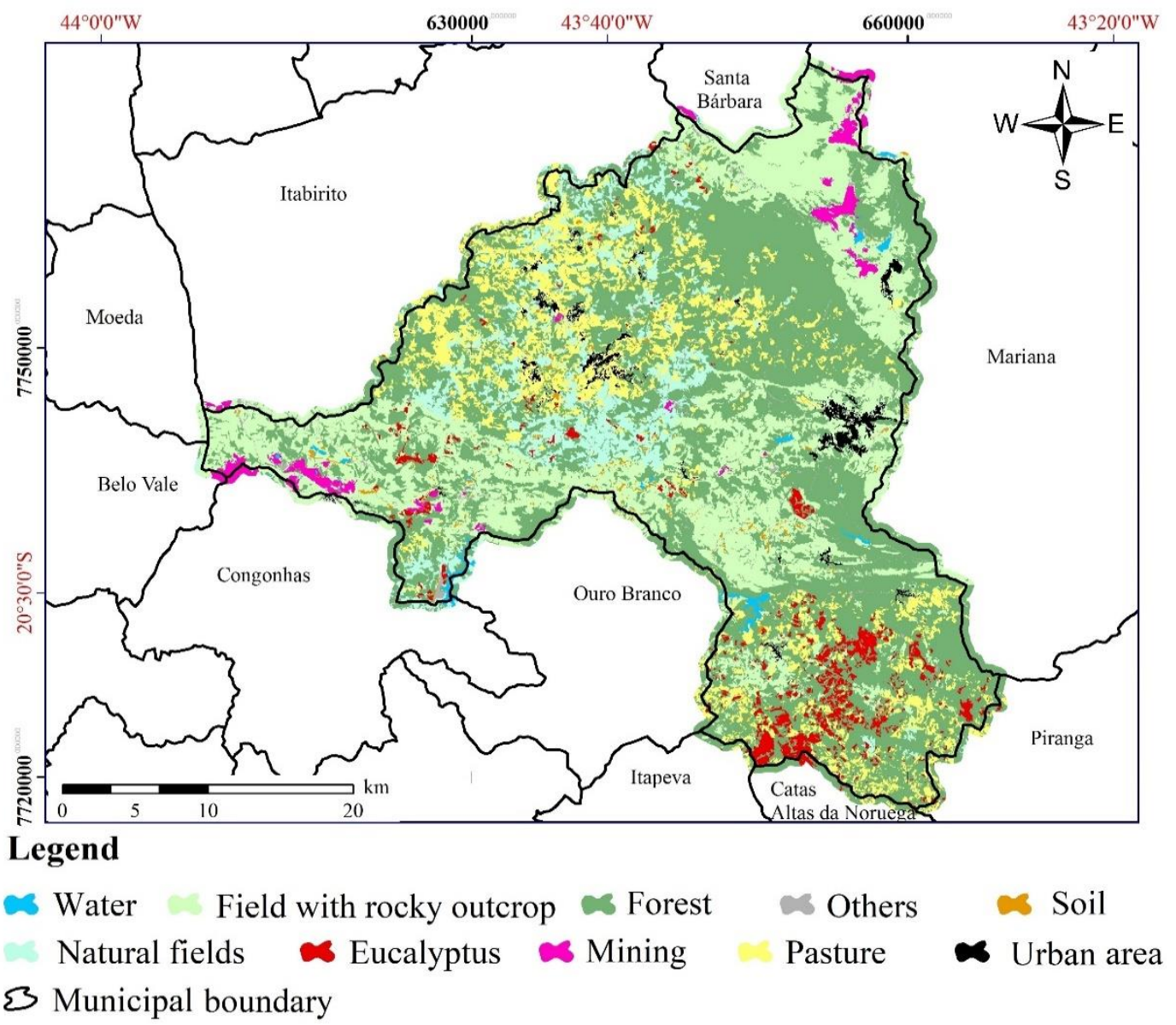

Figure 1. Thematic map of the land use classification in the municipality of Ouro Preto (state of Minas Gerais, Brazil), in 2011.

Figura 1. Mapa temático da classificação de uso do solo do município de Ouro Preto (MG) em 2011.

With the land use classification, the thematic map allowed observing the predominance of the class Semideciduous seasonal forest Montane, followed by field with rocky outcrop and pastures (Table 6). In the thematic map, the major influences of anthropic activities (Figure 2) show that the greatest diversity of interference in natural environments is located in the flatter areas, where it is easier to change land use. In sites where there is presence of mining, the weight tended to the lowest concentration of activities. In the case of fields, they did not show a specific class with weights for elaboration of this result; however, the slope explained its intense use or not.

FLORESTA, Curitiba, PR, v. 48, n. 3, p. 343-354, jul/set. 2018.

Silva. R. A. et.al.

ISSN eletrônico 1982-4688 
Table 6. Area and percentage of land use classes in the municipality of Ouro Preto (state of Minas Gerais, Brazil), in 2011.

Tabela 6. Área e porcentagem das classes de uso do solo no município de Ouro Preto (MG) em 2011.

\begin{tabular}{lrc}
\hline Classes & Area $\left.\mathbf{( k m}^{\mathbf{2}}\right)$ & Percentage $\mathbf{( \% )}$ \\
\hline Forest & 586.2132 & 47.07 \\
Field with rocky outcrop & 317.8939 & 25.52 \\
Pasture & 158.0978 & 12.69 \\
Natural fields & 86.6499 & 6.96 \\
Eucalyptus & 35.9859 & 2.89 \\
Mining & 16.7532 & 1.35 \\
Urban area & 16.4822 & 1.32 \\
Others & 12.8811 & 1.03 \\
Exposed soil & 7.7878 & 0.63 \\
Water & 6.7033 & 0.54 \\
\hline Total Area in Ouro Preto & $\mathbf{1 , 2 4 5 . 4 4 8 4}$ & $\mathbf{1 0 0 . 0 0}$ \\
\hline
\end{tabular}

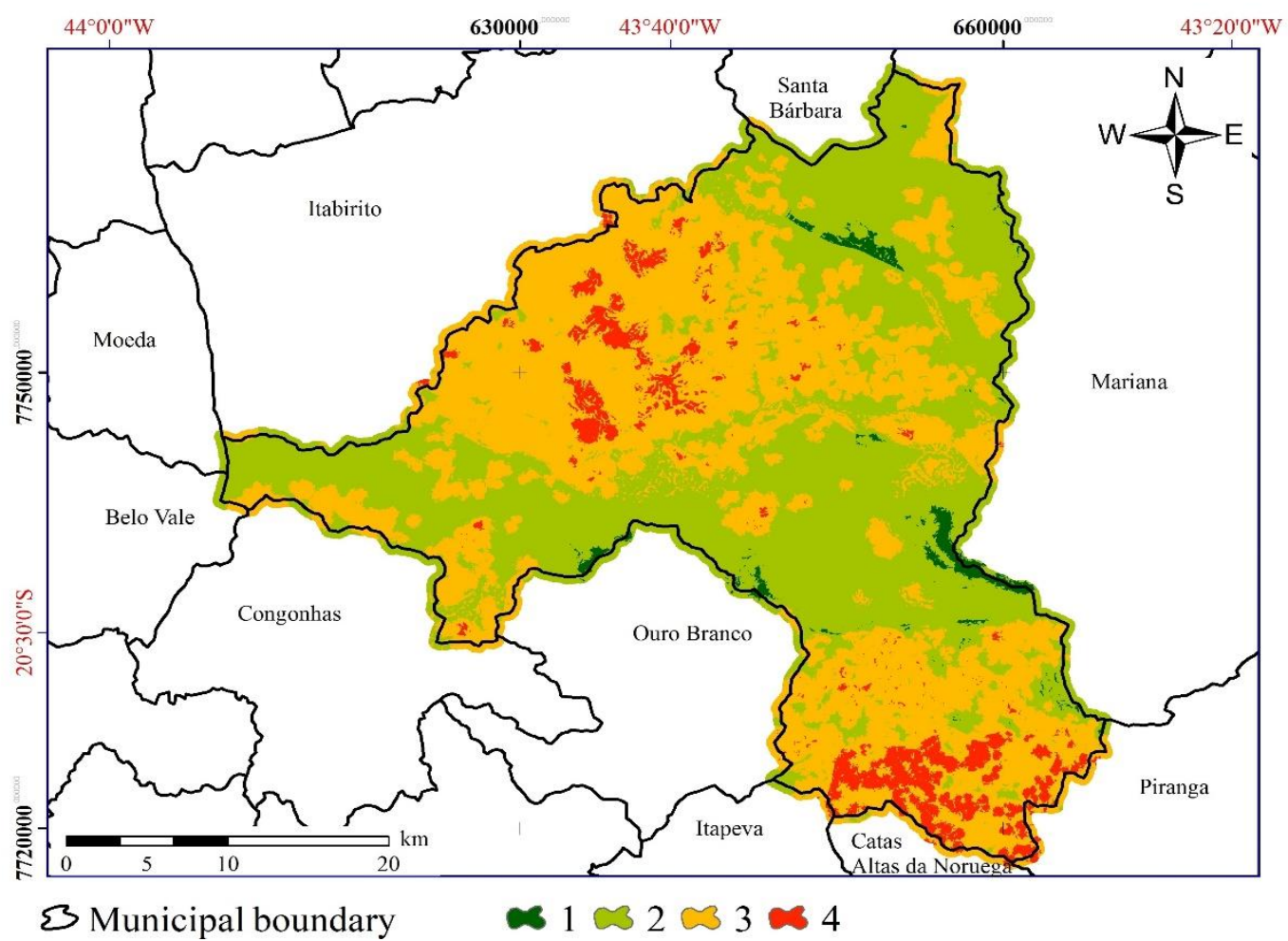

Figure 2. Thematic map with the intensity variation of anthropic activities in the municipality of Ouro Preto (state of Minas Gerais, Brazil). In which: Weight $1=$ sites with lower anthropic activity; Weight $4=$ sites with higher activity; Weight $5=$ did not occur because there was no site in the municipality concentrating activities and/or high levels of weights to reach it.

Figura 2. Mapa temático com a variação da intensidade das atividades antrópicas no município de Ouro Preto (MG). Em que: Peso 1 = locais com menor atividade antrópica; Peso 4 = locais com maior atividade; Peso 5 = não ocorreu devido a nenhum local do município concentrar atividades e/ou altos níveis dos pesos para alcançá-lo.

It was verified that all sites with Weight 1 refer to the greatest possible restrictions and to the sites showing greater difficulty of access for anthropic activities. Thus, they have the largest spacing among all the classes used for elaboration of the thematic map.

In contrast, Weight 2 is heavily influenced by large-scale activities which did not allow diversification or even urbanization in its vicinities. Thus, mining activity was the most influencing class in the landscape, limiting it to diversified uses.

Weight 3 has characteristics related to the existence of anthropic activities. In some cases, it has greater 
diversity, but with small activities. These activities were evidenced in the plains, as in the sites where there is horticultural production. Moreover, they have urbanizations, pastures, smaller mining (sometimes camp) and smaller forests. In sites with greater slope, it was verified the presence of eucalyptus areas near the forests and small pastures, forming an intermediate intensity area of activities.

Concentrating a large amount of anthropic activities, the areas receiving weight 4 are closer to most classes used for mapping. Thus, these areas are configured with several pastures, eucalyptus and larger urban agglomerations in the flatter areas. The areas classified with weight 4 to the north of the municipality are more influenced by pastures and the areas to the south show greater occurrence of eucalyptus areas.

No site was classified as weight 5 , which occurred because there was not enough overlap of classes and weight bands with a higher value capable of reaching it. The internal areas of large forests remained outside the range of influence proposed for elaboration of the thematic map. Large-scale mining limited land use in its areas of influence. The data show that the municipality divides the space among the activities selected for the study, having large areas under influence of the mining activity and the vegetation with dense structure, besides the areas of more intense use with greater range of activities.

\section{Conservation of the environment and landscape}

The population's quality of life is linked directly to the benefits derived from nature, which are related to biodiversity and the environment (KAPHENGST et al., 2014). Based on these factors, the map with intensities of anthropic activities has characteristics related to both population and nature. In this sense, for Bryan et al. (2010), the implementation of conservation plans is usually based on ecological and economic assessment, contrasting the management context which should be social and ecological.

The management also has a great challenge related to the interdisciplinary integration of researchers working in the landscapes, although currently those who are in their early career have more training with interdisciplinary works (RUPPERT-WINKEL et al., 2015). These authors emphasize the need for placing researchers deeply interested in interdisciplinary domains leading these projects. A joint analysis of data and information shows that decision makers shall be interested in greater clarity about the landscape so that their decisions are more accurate.

In Figure 2 is shown the effectiveness of operating conservation units for the environment preservation. The Weight 1, to the north, represents the interior of the main units of the municipality, such as the State Forest of Uaimií and the State Environmental Protection Area (EPA) Cachoeira das Andorinhas; to the south, Itacolomi State Park, Natural Monument State of Itatiaia and the State Park of Serra de Ouro Branco. The Law 18,030/2009 of Minas Gerais was used satisfactorily for the definition of weights. This law recommended greater weight for integral protection units and for private natural heritage reserves (RPPN), half for sustainable use units, and the lower weight for outside areas.

In Figures 1 and 2 are shown the Ouro Preto landscape, where large apparently well-structured regions are observed in relation to existing vegetation cover, without major differences, as found by Silva et al. (2015). However, further studies should be performed to increase knowledge about the quality and biodiversity of these forests, since it is known that the Uaimii Forest, which is partially in Weight 1, is a new forest in an advanced regeneration process after several decades of clearcutting in the region. At the same time, Itacolomi State Park is a site extremely important and with high biodiversity, which also has part of its area in Weight 1, i.e., it is a region destined to the conservation of the environment and the landscape (DRUMMOND et al., 2007).

The map for intensities of anthropic activities must be updated after a certain period so that it is possible to evaluate the dynamics of landscape activities. Based on the recent evolution of anthropic activities and the areas conserved from the field trips and historical satellite imagery, it was noticed that, every five years, the greatest differences can be perceived in the municipal scale. Fan et al. (2008) analyzed land use for five years and verified many transformations in their study areas, with reservations regarding the data usage for a long-term planning, in which a greater recurrence time would be necessary to obtain better accuracy in the manager decisions.

This recurrence time of five years was also based on the analysis of transformations in the landscape. For instance, there was an increase in one of the mining pits, which grew from 0 to $5 \mathrm{~km}$ in diameter between 2000 and 2005 in the district of Miguel Burnier, where it obtained Weights 2 and 3. Moreover, it was observed that the eucalyptus forestry increased in the region of Santa Rita de Ouro Preto, to the detriment of a modest area occupied by pastures. In addition, urbanizations were developed mainly in the regions of the districts of Cachoeira do Campo and Amarantina, where Weights 3 and 4 are concentrated. The physical changes in landscapes of the municipality reflect the economy, which provided profound transformations, thus requiring that the location and intensity of anthropic activities became important factors for the understanding of landscape. For Luginbühl (2012), the landscape must be worked in its transversality, which includes the economy, reinforcing the need to add more social and ecological perspectives to the contexts under analysis.

FLORESTA, Curitiba, PR, v. 48, n. 3, p. 343-354, jul/set. 2018.

Silva. R. A. et.al

ISSN eletrônico 1982-4688 


\section{Use of landscape by population}

The most relevant content discussed by the economy is related to economic growth and to the welfare of society, a theme treated by Adam Smith when analyzing the dynamics of the wealth of nations (UCAK, 2015). The landscape complexity must be considered in its transversality (LUGINBÜHL, 2012). However, the environment conservation is actually represented only by the presence of forests or other natural areas, alluded to a problem rather than its real vital condition to humanity. In the case of the municipality of Ouro Preto, conservation activities are limited to the conservation units and minimum obligations predicted in the Forest Code (Law No. 12.651/2012, which provides for the protection of native vegetation). In this case, some minimum conditions are not achieved. For this reason, there is a population fearful to openly discuss the landscape use, which hinders the achievement of sound economic growth and the goal of a healthy social welfare.

The Ouro Preto region has a history of landscape degradation since the 18th century (ANDRADE, 2008). Part of the problems can be observed from the erosions and history of forest clearcutting. The use dynamics by the transforming actors of the landscape is based on the surrounding of mining activities since the emergence of the municipality (SCHWARCZ; STARLING, 2015). Thus, several uses that are part of citizens' lives, especially from the present generation, are linked to these uses. No real investment is directed at the diversification of economic activities, since Weight 5 has not even occurred. Therefore, a dramatic environmental disaster is not necessary, such as that in the neighboring municipality of Mariana in 2015 (PORTAL BRASIL, 2015), to announce a major environmental and economic crisis in the region of Ouro Preto. The economic dependence of mining, conditioned throughout the history of the municipality, is indicative of future adversities (REIS, 2012).

With respect to historical heritage, the residents report investments in their restoration, with taxes coming from mining activity, which are not adequate to heritage conservation. Agricultural crops, milk production and fruit-growing face the same lack of subsides, constituting small economic activities. In this sense, Carvalho and Gallo (2012) proposed the elaboration and implementation of programs to promote production and marketing, improvement of productive infrastructure, promotion of value added to products, acquisition of equipment, and adequate technical assistance. All these procedures should be implemented in the regions classified as Weights 3 and 4 due to the greater concentration of people and less influenced by mining activities. These proposals must respect the SNUC guidelines in the sites where there are conservation units.

The management of the municipality of Ouro Preto became it dependent on mining activity, a particularity that, in practice, creates great problems for conservation. Likewise, there is a disproportionate dependence on biodiversity related to poor households for the maintenance of daily needs (THE ECONOMICS OF ECOSYSTEMS AND BIODIVERSITY, 2010). In the municipality, the mining, agriculture and subsistence livestock are present in weights 3 and 4. Agriculture, fishing and forestry are dominant activities around the world, with about $37 \%$ of the labor force; in Brazil, they correspond to 15.7\% (CENTRAL INTELLIGENCE AGENCY, 2013). Similarly, in the municipality, these activities represent a great part of the occupation of inhabitants and space, demanding attention in the regulation and inspection.

These high dependencies are responsible for the major degradations in the landscape. Analyzing the Atlas of Human Development in Brazil, data from the municipality of Ouro Preto indicate that 20\% of the richest people hold 55.55\% of the wealth (PROGRAMA DAS NAÇÕES UNIDAS PARA O DESENVOLVIMENTO et al., 2013). It is noted that there are problems regarding the adequacy of the income distribution, which therefore end up favoring the maintenance of this scenario and increasing the landscape degradation. It can also be added that, from the social transformations, changes are made in the territory due to the dynamic nature of landscapes, which are modified as a function of the society and the spatial mosaics present in the municipality over time.

For the environment conservation, the generated currencies should be better distributed so that the population receives the means to understand the landscape where they live and to create new alternatives for income generation, which must also promote a preserved environment. In this way, working the landscape aids managers to think about the best alternatives to solve the found problems (RAYMOND et al., 2015). Over time, the technology evolution tends to meet the demands generated by the environment degradation.

Another activity that received relevance in the municipality of Ouro Preto was tourism, although not well regulated. However, it still contributes largely to the degradation observed from the various levels of erosion present in the fields (SILVA et al., 2015). Tourism is very strong in the areas located in Weights 2 and 3; it is emphasized that its predominance occurs especially in areas where large mining decreases its influence.

The jobs generated by the mining activity favor the individuals beyond the municipality limits, contributing strongly to the Brazilian economy; however, this situation only increases dependence on the activity. The income obtained with the mining activity by the municipality is evidenced when observing the period between 2008 and 2010, in which the ICMS collection ranged between 35\% and 40\% (CARVALHO et al., 2012). However, this income obtained by the municipality become low due to the degradation provoked to the landscape and the local society. This 
reality can be minimized by reversing current income in the diversification of human activities and strengthening local communities focused on sustainable development.

\section{Landscape conservation criteria and measures}

Based on the aforementioned approaches, the best ways to preserve the environment can be expanded through municipal investments related to the promotion of small and medium producers in the municipality, which can be performed through incentives aimed to diversify anthropic activities, besides improving the qualification of the existing staff in the city hall (INTERNATIONAL COUNCIL FOR SCIENCE; INTERNATIONAL SOCIAL SCIENCE COUNCIL, 2015). These actions may result in increased employment opportunities for the population in the regions with Weights 3 and 4. Simultaneously, they can encourage conservation with Payments for Environmental Services, especially in the regions with Weight 3, besides fomenting the conservation of the Permanent Preservation Areas (PPAs) and Legal Reserves (LR) existing along the municipality, since these areas are outside conservation units and show major conservation problems. The PPA and LR have their values increased when considering the surrounding conservation units, since they end up serving as wildlife corridors or step-stones, among the forest fragments.

\section{CONCLUSION}

- The results from the use of methodology are relevant in order to define the current intensity of anthropic activities in the landscape, as well as for the future economic and ecological planning.

- The land use mapping, together with the intensity of anthropogenic activities, improved the understanding on the landscape complexity due to the aggregation of social information, which is unique in each landscape.

- The methodology applied over the years may add more classes of activities as a function of the changes in anthropic activities.

- The understanding of the spatial location of anthropic processes, either by consolidation or isolation of activities, aided to understand the current landscape of the municipality of Ouro Preto (state of Minas Gerais, Brazil).

- Other activities not described in the present research, or those with smaller scales, may be included according to the interest of managers and landscape transformers. The methodology can also be used in larger regions. The limitations regarding their use, in these cases, are based on the detail level of the classes, as well as their validation, which will depend on the financial and time availability.

- In the long term, measures to improve management through the creation of alternatives to human activities have complex obstacles that, once met, can show real benefits. The new described possibilities can reduce the dependence of families economically vulnerable to biodiversity and to large-scale mining activity, thus helping to preserve the landscape in its totality, including ecosystems vital to humanity, as well as all their tangible and intangible assets.

\section{ACKNOWLEDGMENTS}

The authors would like to thank the State Forestry Institute (IEF) of the Ouro Preto region; the Coordination for the Improvement of Higher Education Personnel (CAPES); to the Federal University of Lavras (UFLA); Laboratoire Dynamiques Sociales et Recomposition des Espaces (LADYSS); and to the friends who helped in the data collection.

\section{REFERENCES}

ANDRADE, F. E. de. Entre a roça e o engenho: roceiros e fazendeiros em Minas Gerais, primeira metade do século XIX. 1. ed. Viçosa: Editora da Universidade Federal de Viçosa, v. 1, 2008. 255 p.

BRYAN, B. A. et al. Comparing Spatially Explicit Ecological and Social Values for Natural Areas to Identify Effective Conservation Strategies. Conservation Biology, Hoboken, v. 25, n. 1, pp. 172-181, Set. 2010.

CARVALHO, C. G. et al. A dependência da arrecadação do município de Ouro Preto do setor mineral. Rem: Revista Escola de Minas, Ouro Preto v. 65, n. 3, pp. 385-392, 2012.

CARVALHO, G. C.; GALLO, Z. Dependência econômica de pequenos municípios: há alternativas em relação à agroindústria canavieira em Pradópolis-SP? Revista Temas de Administração Pública, Araraquara, v. 4, n. 7, Dez. 2012.

FLORESTA, Curitiba, PR, v. 48, n. 3, p. 343-354, jul/set. 2018.

Silva. R. A. et.al.

ISSN eletrônico 1982-4688 
CENTRAL INTELLIGENCE AGENCY. The World Factbook 2013-14. Washington, DC: Central Intelligence Agency, 2013. Disponível em: <https://www.cia.gov/library/publications/the-world-factbook/index.html>. Acesso em: Fev. 2016.

CROSSMAN, N.D.; BRYAN, B.A.; KING, D. Integration of landscape-scale and site-scale metrics for prioritising investments in natural capital. In: 18th World IMACS / MODSIM Congress, Cairns, Australia 1317 July 2009. Disponível em: <www.mssanz.org.au/modsim09/F12/crossman_F12.pdf〉. Acesso em: Fev. 2012.

DRUMmond, G. M.; MARTins, C. S.; TANiGUCHI, M. (coordenadores). Plano de Manejo do Parque Estadual do Itacolomi. Belo Horizonte: Instituto Estadual de Florestas -IEF, out. 2007. 263 p.

ENVIRONMENTAL SYSTEMS RESEARCH INSTITUTE. ArcGIS 9.2 Desktop Help, Weighted Overlay, Release 9.2, 2008. New York, Environmental Systems Research Institute - ESRI, 2008. Disponível em: <http://webhelp.esri.com/arcgisdesktop/9.2/index.cfm?TopicName=weighted_overlay>. Acesso em: Jan. 2015.

FAN, F.; WANG, Y.; WANG, Z. Temporal and spatial change detecting (1998-2003) and predicting of land use and land cover in Core corridor of Pearl River Delta (China) by using TM and ETM+ images. Environmental Monitoring and Assessment, Dordrecht, v. 137, n. 1-3, pp. 127-147, Fev. 2008.

INTERNATIONAL COUNCIL FOR SCIENCE; INTERNATIONAL SOCIAL SCIENCE COUNCIL. Review of the Sustainable Development Goals: The Science Perspective. Paris, INTERNATIONAL COUNCIL FOR SCIENCE - ICSU, 2015. 92 p.

KAPHENGST, T. et al. Quality of Life, Wellbeing and Biodiversity. The role of biodiversity in future development. In: Deutsche Gesellschaft für Internationale Zusammenarbeit (GIZ) GmbH. Ecologic Institute Berlin. 2014.

LARRUE, C. et al. Ressource paysagère et territoire: une nécessaire régulation? In: LUGINBÜHL, Y.; TERRASSON, D. Paysage et développement durable. Paris, Editora Quae, 2013. 312 p.

LUGINBÜHL, Y. La mise en scène du monde : Construction du paysage européen. Paris, CNRS Éditions, 2012. $432 \mathrm{p}$.

PELLIN, A. et al. Avaliação Ambiental Estratégica no Brasil: considerações a respeito do papel das agências multilaterais de desenvolvimento. Revista Engenharia Sanitária e Ambiental, Rio de Janeiro, v. 16, n. 1, pp. 27-36, Mar. 2011.

PROGRAMA DAS NAÇÕES UNIDAS PARA O DESENVOLVIMENTO; INSTITUTO DE PESQUISA ECONÔMICA APLICADA; FUNDAÇÃO JOÃO PINHEIRO. Índice de Desenvolvimento Humano Municipal Brasileiro. Brasília: PNUD, IPEA, FJP, 2013. 96 p. Disponível em: <http://www.pnud.org.br/arquivos/idhmbrasileiro-atlas-2013.pdf>. Acesso em: Jan. 2016.

PORTAL BRASIL. Governo trabalha para minimizar impacto ambiental e recuperar bacia do Rio Doce. Brasil: Portal Brasil, Meio Ambiente, dez, 2015. Disponível em: 〈http://www.brasil.gov.br/>. Acesso em: Jan. 2016.

RAPPAPORT, D. I.; TAMBOSI, L. R.; METZGER, J. P. A landscape triage approach: combining spatial andtemporal dynamics to prioritize restoration andconservation. Journal of Applied Ecology, Hoboken, v. 52, n. 3, pp. 590-601, Jun. 2015.

RAYMOND, R. et al. Les atlas de paysages: méthode pour l'identification, la caractérisation et la qualification des paysages. Ministère de l'Écologie, du Développement durable et de l'Énergie. França: Ministère de l'Écologie, du Développement durable et de l'Énergie, 2015. 115 p.

REIS, L. Dependência da mineração é risco de crise em várias cidades mineiras. Brasil: Hoje em dia, 2012. Disponível em: 〈http://www.hojeemdia.com.br/noticias/economia-e-negocios/>. Acesso em: Jan. 2016.

RUPPERT-WINKEL, C. et al. Characteristics, emerging needs, and challenges of transdisciplinary sustainability science: experiences from the German Social-Ecological Research Program. Ecology and Society, Wolfville, v. 20, n. 3, art. 13, 2015.

SCHWARCZ, L. M.; STARLING, H. M. Brasil: uma biografia. São Paulo: Companhia das Letras, 2015. 846 p.

SILVA, R. A. et al. Avaliação da cobertura florestal na paisagem de Mata Atlântica no ano de 2010, na região de Ouro Preto, MG. Cerne, Lavras, v. 21, n. 2, Abr./Jun. 2015. 
THE ECONOMICS OF ECOSYSTEMS AND BIODIVERSITY. Mainstreaming the Economics of Nature: A Synthesis of the Approach, Conclusions and Recommendations of TEEB. Bruxelas, 2010. 36 p.

UCAK, A. Adam Smith: The Inspirer of Modern Growth Theories. Procedia - Social and Behavioral Sciences, Netherlands, v. 195, pp. 663-672, Jul. 2015.

VILLARD, M. A.; METZGER, J. P. Review: Beyond the fragmentation debate: a conceptual model to predict when habitat configuration really matters. Journal of Applied Ecology, Hoboken, v. 51, p. 309-318, Jan. 2014.

FLORESTA, Curitiba, PR, v. 48, n. 3, p. 343-354, jul/set. 2018. 
FLORESTA, Curitiba, PR, v. 48, n. 3, p. 343-354, jul/set. 2018 Silva. R. A et.al. 